\title{
Potential side effects of directly Acting Antivirals (DAAs) after one and three months of treatment among EGYPTIAN elderly patients
}

\author{
Ahmed Abd Elrahim Ali', Reem M.S. Elbedewy ${ }^{1}$, Ahmed Fouad Sherief ${ }^{2}$, Ossama Ashraf ${ }^{3}$,Hager \\ Ahmed $^{3}$ Shereen Moustafa Mousa ${ }^{1}$ \\ 1-Geriatrics and Gerontology Department, Faculty of Medicine, Ain Shams University \\ 2-Tropical Medicine Department, Faculty of Medicine, Ain Shams University \\ 3-Internal Medicine Department, Faculty of Medicine, Ain Shams University
}

\begin{abstract}
Background: Hepatitis C virus (HCV) is a major health problem worldwide. In 2015, the global prevalence of HCV infection was $1.0 \%$, with the highest prevalence in the Eastern Mediterranean Region (2.3\%). The highest prevalence of HCV infection is present in Egypt, with $92.5 \%$ of patients infected with genotype 4. Old people with chronic hepatitis $\mathrm{C}(\mathrm{HCV})$ were considered a difficult-to-treat category. Interferon-free direct-acting antivirals (DAAs) improved treatment adherence and quality of life of old patients. DAAs are approved with high sustained virologic response (SVR) rates and lower side effects.
\end{abstract}

Objective: to detect prevalence of common side effects of DDAs at one month duration and compare it to their prevalence after three months of treatment among Egyptian elderly people.

Methods: it is prospective cohort study included 113 elderly patient (more than 60 years old) who are confirmed to be hepatitis $c$ positive by polymerase chain reaction testing for hepatitis $c$ and are candidate to receive hepatitis $C$ virus treatment from Virology Center of Ain Shams University Hospitals. All participants assessed before treatment, 1 month after starting treatment, and after three months of treatment to common side effects of DAAs.

Results: the study included 113 patients, there was some missing data mainly after three months, and it showed there was overall improving in DAAs side effects after three months of treatment in comparison to the first month. Side effects after one month of treatment doesn't affect DAAs continuity and response which was achieved in $84.8 \%$ of the patients and all side effects decreased significantly after three months. Most of these side effects happened within one month of treatment. There was strong relation between side effects after one month and age. Least percentage of side effects $(28.4 \%$ ) happened with Sofosbuvir+ Daclatasvir (sof + dac) regimen and highest percentage $(44.6 \%)$ with Sofosbuvir+ Daclatasvir+Ribavirin for 24 weeks (sof+dac+riba 24 regimen).

Conclusion: DAAs therapy has been developed and has been found to be a well-tolerated therapy, safe and low adverse side effects among elderly people.

Keywords: Direct-acting antivirals, HCV, Egypt, OId.

\section{Background}

Hepatitis $\mathrm{C}$ virus (HCV) is a major health problem worldwide (Omran et al., 2018). The highest prevalence of HCV infection is present in Egypt, with $92.5 \%$ of patients infected with genotype 4 (Smith et al., 2014).

In 2015, an Egyptian demographic survey study stated that $6.3 \%$ of the population have been tested $\mathrm{HCV}$
Antibody ( $\mathrm{HCV} \mathrm{Ab}$ ) positive and the rate of infection increases with age reaching $27.6 \%$ in those aged (55-60 years) (Ministry of Health and Population [Egypt], 2015; Blach et al., 2017).

Egypt launched a large program for controlling HCV in the country which utilized a wide network of specialized viral hepatitis treatment centers covering 
the country to secure access to antiviral medications (El-Akel et al., 2017; El Kassas et al., 2018).

Old people always represent a therapeutic challenge in many aspects because of the associated co-morbidities and the possible used polypharmacy. The age of 65 years and more is agreed as the definition for old population, and the size of this group varies from a country to another, in Egypt this age starts at 60 years old which the age of retirement (World Health Organization, 2018; Egypt demographic profile, 2018).

Since the first introduction of the interferon-alone treatment, the antiviral treatments for chronic hepatitis $\mathrm{C}$ have developed dramatically through the combination therapy of peg-interferon- $\alpha$ (PegIFN) and ribavirin(RBV) to direct-acting antiviral agents (Kim et al., 2015).

Greater understanding of the hepatitis $\mathrm{C}$ virus (HCV) genome and proteins has enabled efforts to improve efficacy and tolerability of HCV treatment. Notably, this has led to the development of multiple direct-acting antivirals (DAAs), which are medications targeted at specific steps within the HCV life cycle (Scheel and Rice, 2013).

Severe side effects were observed in patients treated with PegIFN and RBV as compared to sofosbuvir based treatment as anemia, fever, bone marrow depression, weight loss, mood disorders and influenza-like symptoms. The most common DAAs general side effects including headache, fatigue, irritability, nausea and diarrhea and it ranges from different types of drug used (Sandmann et al., 2019).

Daclatasvir (Daklinza) was reported to cause the following side effects, fatigue (14\%), headache (14\%), nausea (8\%), and diarrhea (5\%) (Bifano et al., 2015).

Sofosbuvir (Sovaldi) Sofosbuvir is generally welltolerated. The most common adverse effects observed with sofosbuvir, when used in combination with ribavirin, have been fatigue and headache. (Desnoyer et al., 2016).

(Ribavirin) usually causes Fatigue (70\%), pyrexia $(55 \%)$, Nausea $(47 \%)$, diarrhea $(22 \%)$, vomiting $(14 \%)$, headache $(66 \%)$ and dizziness (26\%) (Ibarra et al., 2011).

No AEs were observed in patients receiving daclatasvir ${ }^{\circledR} /$ sofosbuvir $\AA$, with $\mathrm{RBV}$ which led to discontinuation of therapy (Leory et al., 2016).

\section{Aim of the work:}

To detect prevalence of common side effects of DDAs at one month duration and compare it to their prevalence after three months of treatment among Egyptian elderly people

\section{Methods}

The study is prospective cohort study in which 113 patients were participated on the study.52 male and 61 female with mean age $(64.48 \pm 4.29)$. The collected data is from Ain Shams University virology center (geriatrics clinic), over 6 months from 1/3/2019 till 30/8/2019. socio-demographic data were collected including years of education presented in years (more than 12 year education, 6-12 year education, below 6 year education and illiterate which can not read or write), occupation (still working or retired), marital status...etc.

All participants underwent:

- Comprehensive geriatric assessment that consists of structured interview questionnaire including socio-demographic data (age and sex... etc) and medical and surgical history with inquiry on drug side effects, full physical examination.

- 2-Assessment of depression was depression was done by Patient Health Questionnaire-2 (PHQ2) (Kroenke et al.,2003)

According to treatment protocol used in Virology Center of Ain Shams University Hospitals, there are three regimens used in treatment:

1) sofosbuvir+ daclatasvir for 12 weeks

2) sofosbuvir+ daclatasvir+ribavirin for 12 weeks.

3) sofosbuvir+ daclatasvir+ribavirin for 24 weeks.

The duration of treatment protocols may be continued up to 24 weeks (6 months)

(sofosbuvir+ daclatasvir+ribavirin for 24 weeks) but we followed the patients up to 12 weeks ( 3 months) as the other two treatment regimens end at this time.

\section{Inclusion Criteria:}

- Patients (males and females) $\geq 60$ years old

- Patients who accept to participate in the study

- HCV RNA positive by polymerase chain reaction for hepatitis $\mathrm{c}$ and candidate to treatment from virology center at Ain Shams University Hospitals (Supreme Council and Nccvh, 2016).

Exclusion Criteria:

- Patients who refuse to participate in the study

- Patients who are younger than 60 years old

- Patients not fitting the criteria for receiving treatment which are:

- Patients classified as child c stage with the CHILD-PUGH classification system (Pugh et al., 1973).

- Patients with platelet count less than 50000/mm3

- Hepatocellular carcinoma except 6 months after intervention aiming at cure with no evidence of activity by dynamic imaging (CT or MRI)

- Extra hepatic malignancy except after two years of disease-free interval

- Uncontrolled Diabetes Mellitus (HBA1C more than $9 \%$ )

According to treatment protocols there were three drugs used in treatment Daclatasvir (Daklinza),Sofosbuvir (Sovaldi)and Ribavirin, and most common side effects including headache, fatigue, irritability, nausea and diarrhea and it ranges from different types of drug used (Sandmann et al., 2019). 


\section{Data Management and Analysis:}

Data were collected, revised, coded and entered to the Statistical Package for Social Science (IBM SPSS) version 23. The quantitative data were presented as mean, standard deviations and ranges when parametric and median, inter-quartile range (IQR) when data found non-parametric. Also qualitative variables were presented as number and percentages.

The comparison between groups regarding qualitative data was done by using Chi-square test and/or Fisher exact test when the expected count in any cell found less than 5 .

The confidence interval was set to $95 \%$ and the margin of error accepted was set to $5 \%$. So, the p-value was considered significant as the following:

$\mathrm{P}$-value $>0.05$ : Non significant (NS)

$\mathrm{P}$-value $<0.05:$ Significant $(\mathrm{S})$

P-value < 0.01: Highly significant $(\mathrm{HS})$.

\section{Results:}

The study included 113 patients 61 female and 52 male; there were some missing data of the side effects of DAAs at 3 months that were reported in tables. Table (1) showed socio-demographic data with mean age $64.48 \pm 4.29$; with all included patients in the study having $\mathrm{HCV}$ and no has co infection of HCV and HBV. Table (2) showed most common side effects and its prevalence after one and three months of treatment. After one month the most common side effects were loss of appetite $(57.5 \%)$, nausea $(54.9 \%)$, impaired concentration $(46.9 \%)$, fatigue $(40.7 \%)$ and headache (29.2\%).the most common side effects after three months were loss of appetite $(23 \%)$, fatigue $(22.1 \%)$, nausea $(22.1 \%)$ and impaired concentration $(22 \%)$.

Table (3): Description of Socio-demographic data:

\begin{tabular}{c|cc}
\hline \multirow{2}{*}{ Age } & Mean \pm SD & No. $=113$ \\
& Range & $64.48 \pm 4.29$ \\
Gender & Female & $60-77$ \\
& Male & $61(54.0 \%)$ \\
Marital state & Married & $52(46.0 \%)$ \\
& Single & $72(81.4 \%)$ \\
& Widow & $13(6.2 \%)$ \\
& Divorced & $1(0.9 \%)$ \\
Occupation & Working & $54(47.8 \%)$ \\
& House wife/ retired & $59(52.2 \%)$ \\
Education & Illiterate (can't read or write) & $44(38.9 \%)$ \\
& Less than 6 & $13(11.5 \%)$ \\
& $6-12$ & $16(14.2 \%)$ \\
HCV+HBV & More than 12 & $40(35.4 \%)$ \\
& Yes & $0(0.0 \%)$ \\
& No & $113(100.0 \%)$ \\
\hline
\end{tabular}

Table (3) showed comparison between side effects after one and three months of treatment.it showed highly statistically significance decline found in impaired concentration, fatigue, nausea, insomnia, depression and loss of appetite as regard DAAs side effects
Table (1): Prevalence of common side effects of DAAs after one and three months

\begin{tabular}{|c|c|c|c|c|c|}
\hline \\
\hline \multirow{3}{*}{ Diarrhea } & & $\begin{array}{l}\text { After one } \\
\text { month }\end{array}$ & Total no. & $\begin{array}{c}\text { After three } \\
\text { months }\end{array}$ & Total no. \\
\hline & $\begin{array}{l}\text { Yes } \\
\text { No }\end{array}$ & $\begin{array}{c}1(0.9 \%) \\
112 \\
(99.1 \%)\end{array}$ & $\begin{array}{c}113 \\
(100 \%)\end{array}$ & $\begin{array}{c}0(0 \%) \\
111(98.2 \\
\%)\end{array}$ & $\begin{array}{c}111 \\
(98.2 \%)\end{array}$ \\
\hline & Missing & $0(0 \%)$ & $0(0 \%)$ & $2(1.8 \%)$ & $2(1.8)$ \\
\hline Fatigue & $\begin{array}{l}\text { Yes } \\
\text { No }\end{array}$ & $\begin{array}{l}46(40.7 \%) \\
67(59.3 \%)\end{array}$ & $\begin{array}{c}113 \\
(100 \%)\end{array}$ & $\begin{array}{l}25(22.1) \\
78(69 \%)\end{array}$ & $\begin{array}{c}103(91.2 \\
\%)\end{array}$ \\
\hline \multirow[b]{2}{*}{ Headache } & Missing & $0(0 \%)$ & $0(0 \%)$ & $10(8.8 \%)$ & $10(8.8)$ \\
\hline & $\begin{array}{l}\text { Yes } \\
\text { No }\end{array}$ & $\begin{array}{l}33(29.2 \%) \\
80(70.8 \%)\end{array}$ & $\begin{array}{c}113(100 \\
\%)\end{array}$ & $\begin{array}{c}4(3.5 \%) \\
102 \\
(90.3 \%)\end{array}$ & 106(93.8) \\
\hline \multirow[b]{2}{*}{ Nausea } & Missing & $0(0 \%)$ & $0(0 \%)$ & $7(6.2 \%)$ & $7(6.2 \%)$ \\
\hline & $\begin{array}{l}\text { Yes } \\
\text { No }\end{array}$ & $\begin{array}{l}62(54.9 \%) \\
50(44.2 \%)\end{array}$ & 112(99.1) & $\begin{array}{l}25(22.1 \%) \\
77(68.1 \%)\end{array}$ & $102(90.3 \%)$ \\
\hline \multirow[b]{2}{*}{ Insomnia } & Missing & $1(0.9)$ & $1(0.9 \%)$ & $11(9.7 \&)$ & $11(9.7)$ \\
\hline & $\begin{array}{l}\text { Yes } \\
\text { No }\end{array}$ & $\begin{array}{c}13(11.5 \%) \\
100(88.5 \%)\end{array}$ & $113(100 \%)$ & $\begin{array}{c}3(2.7 \%) \\
107(94.7 \%)\end{array}$ & $110(97.3 \%)$ \\
\hline \multirow[b]{2}{*}{ Depression } & Missing & $1(0.9 \%)$ & $1(0.9 \%)$ & $3(2.7 \%)$ & $3(2.7 \%)$ \\
\hline & $\begin{array}{l}\text { Yes } \\
\text { No }\end{array}$ & $\begin{array}{c}12(10.6 \%) \\
101(89.4 \%)\end{array}$ & $113(100 \%)$ & $\begin{array}{l}10(8.8 \%) \\
101(89.4)\end{array}$ & 111(98.2\%) \\
\hline \multirow[b]{2}{*}{ Dizziness } & Missing & $0(0 \%)$ & $0(0 \%)$ & $2(1.8 \%)$ & $2(1.8 \%)$ \\
\hline & $\begin{array}{l}\text { Yes } \\
\text { No }\end{array}$ & $\begin{array}{c}12(10.6 \%) \\
101(89.4 \%)\end{array}$ & $113(100 \%)$ & $\begin{array}{c}1(0.9 \%) \\
108(95.6)\end{array}$ & $109(96.5 \%)$ \\
\hline \multirow[b]{2}{*}{$\begin{array}{l}\text { Loss of } \\
\text { appetite }\end{array}$} & Missing & $0(0 \%)$ & $0(0 \%)$ & $4(3.5 \%)$ & $4(3.5 \%)$ \\
\hline & $\begin{array}{l}\text { Yes } \\
\text { No }\end{array}$ & $\begin{array}{l}65(57.5 \%) \\
48(42.5 \%)\end{array}$ & $113(100 \%)$ & $\begin{array}{c}26(23 \%) \\
76(67.3 \%)\end{array}$ & $102(90.3 \%)$ \\
\hline \multirow{3}{*}{$\begin{array}{c}\text { Impaired } \\
\text { concentration }\end{array}$} & Missing & $0(0 \%)$ & $0(0 \%)$ & $11(9.7 \%)$ & $11(9.7 \%)$ \\
\hline & $\begin{array}{l}\text { Yes } \\
\text { No }\end{array}$ & $\begin{array}{l}53(46.9 \%) \\
60(53.1 \%)\end{array}$ & $113(100 \%)$ & $\begin{array}{l}25(22.1 \%) \\
79(69.9 \%)\end{array}$ & $104(92 \%)$ \\
\hline & Missing & $0(0 \%)$ & $0(0 \%)$ & $9(8 \%)$ & $9(8 \%)$ \\
\hline
\end{tabular}

between one and three months of treatment(p value less than or equal 0.01).while dizziness didn't show decline $(\mathrm{p}$ value $=0.09)$, also showed statistically significance decline found in headache after end the treatment in comparison to after one month.

As age may have impact on some side effects Table (4) showed the relation between side effects after one month (as most of side effects happened) and age. There was a highly statistically significance relationship between fatigue, headache, and loss of appetite as side effect after one month of treatment and age ( $\mathrm{p}$ value less than or equal 0.01).with mean age of $65.7( \pm 5.03), 66.7( \pm 4.5)$ and $65.5( \pm 4.5)$ respectively.

Regarding treatment regimen Table (5) shows the relation between each DAAs regimen used in treatment and its side effects after one month we had noticed that the least percentage of side effects $(28.4 \%)$ happened with sofosbuvir+ Daclatasvir (sof+dac) regimen, then sofosbuvir+ Daclatasvir+Ribavirin for 12 weeks (sof+dac+riba 12 weeks) $(37.8 \%)$ and highest percentage (44.6\%) with sofosbuvir+ Daclatasvir+Ribavirin for 24 weeks (sof+dac+riba 24 regimen). 
Table (4): Comparison between DAAs side effects after one and three month treatment

\begin{tabular}{|c|c|c|c|c|c|c|}
\hline & & $\begin{array}{l}\text { After one month } \\
\text { of treatment }\end{array}$ & $\begin{array}{c}\text { Total } \\
\text { Number }\end{array}$ & $\begin{array}{l}\text { After three } \\
\text { months of } \\
\text { treatment }\end{array}$ & $\begin{array}{c}\text { Total } \\
\text { Number }\end{array}$ & P-value \\
\hline $\begin{array}{c}\text { Impaired } \\
\text { Concentration }\end{array}$ & $\begin{array}{l}\text { Yes } \\
\text { No }\end{array}$ & $\begin{array}{l}45 \\
59\end{array}$ & 104 & $\begin{array}{l}25 \\
79\end{array}$ & 104 & 0.000 \\
\hline Fatigue & $\begin{array}{l}\text { Yes } \\
\text { No }\end{array}$ & $\begin{array}{l}38 \\
65\end{array}$ & 103 & $\begin{array}{l}25 \\
78\end{array}$ & 103 & 0.000 \\
\hline Headache & $\begin{array}{l}\text { Yes } \\
\text { No }\end{array}$ & $\begin{array}{l}28 \\
78\end{array}$ & 106 & $\begin{array}{c}4 \\
102\end{array}$ & 106 & 0.003 \\
\hline Nausea & $\begin{array}{l}\text { Yes } \\
\text { No }\end{array}$ & $\begin{array}{l}52 \\
49\end{array}$ & 101 & $\begin{array}{l}25 \\
76\end{array}$ & 101 & 0.000 \\
\hline Insomnia & $\begin{array}{l}\text { Yes } \\
\text { No }\end{array}$ & $\begin{array}{l}12 \\
98\end{array}$ & 110 & $\begin{array}{c}3 \\
107\end{array}$ & 110 & 0.000 \\
\hline Depression & $\begin{array}{l}\text { Yes } \\
\text { No }\end{array}$ & $\begin{array}{l}12 \\
99\end{array}$ & 111 & $\begin{array}{c}10 \\
101\end{array}$ & 111 & 0.000 \\
\hline Dizziness & $\begin{array}{l}\text { Yes } \\
\text { No }\end{array}$ & $\begin{array}{l}10 \\
99\end{array}$ & 109 & $\begin{array}{c}1 \\
108\end{array}$ & 109 & 0.002 \\
\hline $\begin{array}{l}\text { Loss of } \\
\text { appetite }\end{array}$ & $\begin{array}{l}\text { yes } \\
\text { No }\end{array}$ & $\begin{array}{l}55 \\
47\end{array}$ & 102 & $\begin{array}{l}26 \\
76\end{array}$ & 102 & 0.000 \\
\hline
\end{tabular}

Table (5): Relation between side effects after one month and age:

\begin{tabular}{|c|c|c|c|c|c|c|c|c|c|}
\hline \multicolumn{4}{|c|}{ Side effect after one month } & & Number & \multicolumn{3}{|c|}{$\begin{array}{c}\text { Mean Age( standard deviation) } \\
\text { by years }\end{array}$} & $\mathrm{P}$ value \\
\hline \multirow{2}{*}{\multicolumn{3}{|c|}{ Nausea }} & Yes & & $62(55.3 \%)$ & & \multirow{2}{*}{\multicolumn{2}{|c|}{$\begin{array}{l}65.1( \pm 4.6) \\
63.6( \pm 3.7)\end{array}$}} & \\
\hline & & & No & & $50(44.7 \%)$ & & & & 0.08 \\
\hline \multirow{2}{*}{\multicolumn{3}{|c|}{ Fatigue }} & Yes & & $46(40.7 \%)$ & & \multicolumn{2}{|c|}{$65.7( \pm 5.03)$} & \\
\hline & & & No & & $67(59.3 \%)$ & & \multicolumn{2}{|c|}{$63.6( \pm 3.4)$} & 0.01 \\
\hline \multirow{2}{*}{\multicolumn{3}{|c|}{ Headache }} & Yes & & $33(29.4 \%)$ & & \multirow{2}{*}{\multicolumn{2}{|c|}{$\begin{array}{l}66.7( \pm 4.5) \\
63.4( \pm 3.8)\end{array}$}} & \\
\hline & & & No & & $79(70.6 \%)$ & & & & 0.001 \\
\hline \multicolumn{3}{|l|}{ Insomnia } & Yes & & $13(11.6 \%)$ & & \multicolumn{2}{|c|}{$\begin{array}{l}63.4( \pm 3.8) \\
63.5( \pm 2.9)\end{array}$} & 0.2 \\
\hline & & & No & & $99(88.4 \%)$ & & \multicolumn{2}{|c|}{$64.6( \pm 4.45)$} & \\
\hline \multirow{2}{*}{\multicolumn{3}{|c|}{ Depression }} & Yes & & $12(10.6 \%)$ & & \multirow{2}{*}{\multicolumn{2}{|c|}{$\begin{array}{c}65.08( \pm 4.3) \\
64.4( \pm 4.3)\end{array}$}} & 0.6 \\
\hline & & & No & & $101(89.4 \%)$ & & & & \\
\hline \multirow{2}{*}{\multicolumn{3}{|c|}{ Dizziness }} & Yes & & $12(10.6 \%)$ & & \multicolumn{2}{|c|}{$66( \pm 5.1)$} & 0.1 \\
\hline & & & No & & $101(89.4 \%)$ & & \multicolumn{2}{|c|}{$64.2( \pm 4.17)$} & \\
\hline \multirow{2}{*}{\multicolumn{3}{|c|}{ Loss of Appetite }} & Yes & & $65(57.5 \%)$ & & \multirow{2}{*}{\multicolumn{2}{|c|}{$\begin{array}{c}65.5( \pm 4.5) \\
63.04( \pm 3.4)\end{array}$}} & 0.001 \\
\hline & & & No & & $48(42.4 \%)$ & & & & \\
\hline \multirow{2}{*}{\multicolumn{3}{|c|}{ Impaired concentration }} & Yes & & $53(46.9 \%)$ & & \multirow{2}{*}{\multicolumn{2}{|c|}{$\begin{array}{c}65.16( \pm 4.6) \\
63.8( \pm 3.9)\end{array}$}} & 0.1 \\
\hline & & & No & & $60(53.1 \%)$ & & & & \\
\hline \multicolumn{10}{|c|}{ Table (6): Relation between different DAAs regimens used in treatment and its side effects after one month. } \\
\hline $\begin{array}{l}\text { Side effect after one } \\
\text { month }\end{array}$ & & Sof+dac & $\begin{array}{l}\text { Total } \\
\text { number }\end{array}$ & $\begin{array}{l}\text { Sof+dac+ } \\
\text { Riba } 12\end{array}$ & $\begin{array}{l}\text { Total } \\
\text { number }\end{array}$ & $\begin{array}{l}\text { Sof }+ \text { dact } \\
\text { Riba } 24\end{array}$ & $\begin{array}{l}\text { Total } \\
\text { number }\end{array}$ & $\begin{array}{l}P \\
\text { value }\end{array}$ & \\
\hline $\begin{array}{c}\text { Impaired } \\
\text { concentration }\end{array}$ & $\begin{array}{l}\text { Yes } \\
\text { No }\end{array}$ & $\begin{array}{l}30(41.6 \%) \\
42(58.4 \%)\end{array}$ & 72 & $\begin{array}{l}17(50 \%) \\
17(50 \%)\end{array}$ & 34 & $\begin{array}{l}6(85.7 \%) \\
1(14.3 \%)\end{array}$ & 7 & 0.07 & \\
\hline Fatigue & $\begin{array}{l}\text { Yes } \\
\text { No }\end{array}$ & $\begin{array}{l}21(29.1 \%) \\
51(70.9 \%)\end{array}$ & 72 & $\begin{array}{l}19(55.8 \%) \\
15(44.12 \%)\end{array}$ & 34 & $\begin{array}{l}6(85.7 \%) \\
1(14.3 \%)\end{array}$ & 7 & 0.001 & \\
\hline Headache & $\begin{array}{l}\text { Yes } \\
\text { No }\end{array}$ & $\begin{array}{l}17(23.6 \%) \\
55(76.4 \%)\end{array}$ & 72 & $\begin{array}{l}13(38.2 \%) \\
21(61.8 \%)\end{array}$ & 34 & $\begin{array}{l}3(42.8 \%) \\
4(57.2 \%)\end{array}$ & 7 & 0.3 & \\
\hline Nausea & $\begin{array}{l}\text { Yes } \\
\text { No }\end{array}$ & $\begin{array}{l}39(54.1 \%) \\
33(45.9 \%\end{array}$ & 72 & $\begin{array}{l}18(52.9 \%) \\
16(47.1 \%)\end{array}$ & 34 & $\begin{array}{l}5(71.4 \%) \\
2(28.6 \%)\end{array}$ & 7 & 0.7 & \\
\hline Insomnia & $\begin{array}{l}\text { Yes } \\
\text { No }\end{array}$ & $\begin{array}{l}9(12.5 \%) \\
63(87.5 \%)\end{array}$ & 72 & $\begin{array}{l}3(8.8 \%) \\
31(91.2 \%)\end{array}$ & 34 & $\begin{array}{l}1(14.3 \%) \\
6(85.7 \%)\end{array}$ & 7 & 0.8 & \\
\hline Depression & $\begin{array}{l}\text { Yes } \\
\text { No }\end{array}$ & $\begin{array}{l}8(11.11 \%) \\
64(88.8 \%)\end{array}$ & 72 & $\begin{array}{l}3(8.8 \%) \\
31(91.2 \%)\end{array}$ & 34 & $\begin{array}{l}1(14.3 \%) \\
6(85.7 \%)\end{array}$ & 7 & 0.7 & \\
\hline Dizziness & $\begin{array}{l}\text { Yes } \\
\text { No }\end{array}$ & $\begin{array}{l}6(8.3 \%) \\
66(91.7 \%)\end{array}$ & 72 & $\begin{array}{l}6(17.6 \%) \\
28(82.3 \%)\end{array}$ & 34 & $\begin{array}{l}0(0 \%) \\
7(100 \%)\end{array}$ & 7 & 0.3 & \\
\hline Loss of appetite & $\begin{array}{l}\text { Yes } \\
\text { No }\end{array}$ & $\begin{array}{l}34(47.2 \%) \\
38(52.8 \%)\end{array}$ & 72 & $\begin{array}{l}24(70.5 \%) \\
10(29.5 \%)\end{array}$ & 34 & $\begin{array}{l}7(100 \%) \\
0(0 \%)\end{array}$ & 7 & 0.004 & \\
\hline
\end{tabular}




\section{DISCUSSION}

With the revolutionary introduction of DAAs in 2011, there was subsequent increase in sustained virologic response after 12 weeks (SVR12) approaching more than $90 \%$ with satisfying safety profile (Elbaz et al., 2015).

Current international treatment guidelines do not specify the age limit for treating old patients (American Association for the Study of Liver Diseases, 2016).

The Egyptian program is the largest national HCV screening and treatment program in the world. With this screening program and the mass treatment effort that has been the largest in the world so far, Egypt is on a fast track to HCV elimination and has the potential to be the first country to achieve the WHO disease elimination targets. The introduction of DAAs in 2014 led to substantial uptake and scale-up with Egypt's program becoming the largest in the world treating more than 2 million $\mathrm{HCV}$-infected patients. This represents more than half of those treated globally in the last four years (Kandeel et al., 2017).

In this study, we aimed to detect prevalence of common side effects of DDAs at one month duration and compare it to their prevalence after three months of treatment among Egyptian elderly people as one of the most barriers for the use of old antivirals regimens in the vulnerability of elderly.

We had noticed that most of side effects happened within one month of treatment so it was our starting point and followed patients up to three months where two treatment protocol regimens end (sofosbuvir+ daclatasvir for 12 weeks and sofosbuvir+ daclatasvir+ribavirin for 12 weeks).

All involved patients were underwent comprehensive geriatric assessment before starting the treatment then followed one month later to report side effects occurrence. We also followed patients for three months to detect the existence and prevalence of these side effects in comparison to first month. Many of these side effects may occur in elderly due to several factors, so we studied relationship between age and side effects to detect impact. Finally treatment protocol plays an important role in the occurrence of side effects so it was assessed as well.

Although different treatment protocols used for treatment and may be for long duration ( 24 weeks), we didn't counted any patient stopped the treatment due to side effect.

In Pre-era DAAs, PegIFN plus Ribavirin reported several side effects which may be severe and may leads to discontinuation the treatment. It was reported by Fried (2002) that Interferon and ribavirin combination therapy for chronic hepatitis $\mathrm{C}$ produces a number of well-described side effects that are dominated by fatigue, influenza-like symptoms, hematologic abnormalities, and neuropsychiatric symptoms, and most serious side effects was anemia and thrombocytopenia and premature withdrawal from therapy due to adverse events was required in $10 \%$ to
$14 \%$ of participants in registration trials of these agents.

The meticulous monitoring and prompt management of these important issues (drug-drug interactions, and adverse events) in our patients had a great influence on the outcome, which was generally successful, confirming the excellent efficacy of DAAs in this "special population". Achieving SVR is not the sole treatment goal in old patients; other important issues should be taken into consideration when evaluating the outcome of DAAs treatment in old patients. In fact, some studies documented a great benefit both on life expectancy and quality of life in old individuals treated with DAAs (Maor et al., 2016).

Our literature showed most of side effects happened within one month of treatment, and according to different treatment protocol regimen we had found that the least regimen caused side effects was sof + dac regimen with percentage of $(28.4 \%)$ then sof + dac + riba 12 week regimen with percentage of $(37.8 \%)$ and the highest side effects are with sof+dac+riba 24 week regimen with percentage of $(44.6 \%)$.

Based on the studies examined, most of which included phase II and III trials, the current literature favors usage of a SOF-based regimen in patients with cirrhosis, HIV/HCV co-infection and prior treatment failure. As shown, SOF has proven efficacy in both cirrhotic and non-cirrhotic patients and also appears to span all genotypes. The limited drug-drug interactions make it a favorable option in patients co-infected with HIV. Additionally, the route of administration and the favorable side effect profile will lead to overall improvement in quality of life and compliance. Treatment and cure of hepatitis $C$ is now probable, even in "difficult to treat" patients (Hilgenfeldt et al., 2015). Also our literature showed that there were overall improving as regard side effects after three months of treatment in comparison to first month, most of these side effects were impaired concentration (43.2\%), fatigue $(36.8 \%)$, headache $(26.4 \%)$, nausea $(51.4 \%)$, insomnia $(10.9 \%)$, depression $(10.8 \%)$, dizziness $(9.1 \%)$, and loss of appetite $(53.9 \%)$ after one month of treatment, and after three months was (24\%), (24.2\%), $(3.7 \%),(24.7 \%),(2.7 \%),(9 \%),(0.9 \%)$, and $(25.4 \%)$ respectively.

Our study is similar to that Egyptian study of Younossi et al. (2014) showed a significant effect for time on HRQoL after starting treatment by DAAs, it was significantly poorer after $5 / 6$ weeks (peak point of impairment) of therapy than at the baseline and at the end of therapy and then backed to baseline score. This impairment was amplified by the antiviral drugs side effects.

As regard fatigue which is one of the most item that affect quality of life our literature showed that was highly statistically significant improving in fatigue after three months $(24.2 \%)$ in comparison to after one month the treatment $(36.8 \%)$, and this is similar to Virahep-C study, in which 401 patients with HCV 
infection were evaluated for fatigue prior to and after treatment, using validated scales to assess the presence and severity of fatigue. At baseline, $52 \%$ of patients reported having fatigue (Kallman et al., 2007).

In agreement with our study it was shown that besides fatigue, headache and GIT symptoms were most common side effects in both age groups (younger and older than 65 year) (Sherigar et al., 2017). Most adverse events noted in our study were minor and did not require any intervention; adverse events did not differ significantly between the groups

Another study by Ruane et al. (2015) showed that the most common adverse events were fatigue, myalgia, headache, insomnia, and anemia. This was similar to the results of a 2015 study by Ruane et al. of sofosbuvir and ribavirin treatment in patients with $\mathrm{HCV}$ infection and genotype 4 .

Also our literature was similar to this Egyptian study which showed that 22 patients of the treated population (12.4\%) experienced fatigue, 21 patients (11.9\%) experienced headache, 11 patients $(6.2 \%)$ experienced diarrhea, and 9 patients $(5.1 \%)$ experienced nausea. This came in accordance with Babatin et al. who studied 96 patients with chronic HCV genotype 4 who were treated by Sofosbuvir plus Daclatasvir or Sofosbuvir plus Simeprevir. The Sofosbuvir plus Daclatasvir arm included 40 patients. $42.5 \%$ of those patients developed adverse events where $27.5 \%$ suffered fatigue, $25 \%$ suffered headache, $7.5 \%$ suffered nausea, $10 \%$ suffered insomnia, $3 \%$ suffered nausea, and 4\% suffered diarrhea (Ahmed et al., 2018).

In relation to age we had found highly statistically significance relation between side effects and older ages after one month, as there is correlation between fatigue, headache and loss of appetite and increasing age with mean age 65.7 $( \pm 5.03)(\mathrm{p}=0.01), 66.7( \pm 4.5)$ $(\mathrm{p}=0.001)$ and $65.5( \pm 4.5)(\mathrm{p}=0.001)$ respectively.

It suggests that there may be a correlation between side effects and older ages but it need more comprehensive geriatric assessment and more close monitoring and follow up.

That agrees with Pariente et al. (2019) which showed the rate of severe adverse events tended to be greater in patients older than 64 years of age .Patient-reported overall tolerance was excellent in all age groups, and patient-reported fatigue decreased during and after treatment, independent of age.

Also another study showed that $41 \%$ (32 out of 78 ) of enrolled patients experienced adverse reactions, of these $40 \%$ were in those under 65 years while $60 \%$ was in patients older than 65 years, SVR was achieve in $88 \%$ of the patients (including drop-out). We had 4 drop-out treatment due to major adverse reaction (heart and lung related). Even if new antiviral drugs seem to be promising, according to SVR, they require careful follow-up, possibly managed by clinician and hospital pharmacist, to avoid unrecognized side effects which may affect adherence and the real impact of these drugs on chronically infected subjects (Nappi et al., 2017).
In contrast Vermehren et al. (2016) showed no significant difference as regard side effects between elderly and other age group as a total of $63 \%$ ( $\mathrm{n}=$ 264/417) patients experienced at least one adverse event during the treatment period. Adverse events were generally mild and the number of adverse events was not significantly different between patients $<65$ years and patients $\geq 65$ years respectively ( $63 \%$ vs. $65 \%$ ), The most common adverse events were fatigue $(35 \%$ and $37 \%)$, dyspnea $(11 \%$ and $15 \%$; only patients on RBV treatment affected), headache $(22 \%$ and $11 \%)$, pruritus (7\% and 10\%), rash (7\% and 2\%) and insomnia (6\% and $7 \%$ ) in patients $<65$ and $\geq 65$ years of age respectively.

Other studies are needed to assess impact of age on different DAAs side effects.

\section{CONCLUSION}

DAAs therapy has been found to be a well-tolerated therapy, safe and low adverse side effects among Egyptian elderly people, but further assessment and follow up for longer time period is require to avoid unpleasant events in already chronically ill age group.

\section{References}

1. Ahmed, O. A., Safwat, E., Khalifa, M. O., Elshafie, A. I., Fouad, M. H. A., Salama, M. M., \& Abd-Elsalam, S Sofosbuvir plus daclatasvir in treatment of chronic hepatitis $C$ genotype 4 infection in a cohort of Egyptian patients: an experiment the size of Egyptian village. International journal of hepatology, 2018

2. American Association for the Study of Liver Diseases, Infectious Diseases Society of America. Initial treatment of $\mathrm{HCV}$ infection. Recommendations for testing, managing, and treating hepatitis C. http://www.hcvguidelines.org/fullreport/initial-treat ment-hcv-infection. 2016.

3. Bifano M, Adamczyk R, Hwang C, Kandoussi H, Marion A Bertz RJ. An open-label investigation into drug-drug interactions between multiple doses of daclatasvir and singledose cyclosporine or tacrolimus in healthy subjects. Clin Drug Investig. 2015; 35:281-9.

4. Blach S, Zeuzem S, Manns M, Altraif I, Duberg AS, Muljono DH, Waked I, Alavian SM, Lee MH, Negro F, Abaalkhail F. Global prevalence and genotype distribution of hepatitis $C$ virus infection in 2015: a modelling study. Lancet Gastroenterol Hepatol 2017; 2(3):161-176.

5. Desnoyer A, Pospai D, Lê MP, et al. Pharmacokinetics, safety and efficacy of a full dose sofosbuvir-based regimen given daily in hemodialysis patients with chronic hepatitis $C$. J Hepatol. 2016; 65:40-7.

6. Egypt demographic profile, CIA world fact book last updated January 2018. https: //www.cia.gov/libra ry/publi catio ns/theworld -factb ook/geos/eg.html. Accessed 12 Jan 2018

7. El Kassas M, Elbaz T, Elsharkawy A, Omar H, Esmat G. HCV in Egypt, prevention, treatment and key barriers to elimination. Expert Rev Anti-infective Ther 2018; 16(4):345350.

8. El Kassas M, Elbaz T, Hafez E, Esmat G. Safety of direct antiviral agents in the management of hepatitis $C$. Expert Opin Drug Saf 2016; 15(12):1643-1652.

9. El-Akel W, El-Sayed MH, El Kassas M, El-Serafy M, Khairy M, Elsaeed K, Kabil K, Hassany M, Shawky A, Yosry A, Shaker MK. National treatment programme of hepatitis $C$ in Egypt: hepatitis C virus model of care. J Viral Hepat 2017; 24(4):262-267.

10. Fried, M. W. Side effects of therapy of hepatitis $C$ and their 
management. Hepatology 2002; 36(S1), S237-S244.

11. Hilgenfeldt EG, Schlachterman A, Firpi RJ. Hepatitis C: treatment of difficult to treat patients. World journal of hepatology. 2015; 7(15):1953.

12. Kallman, J., O'Neil, M.M., Larive, B., Boparai, N., Calabrese, L. and Younossi, Z.M. Fatigue and health-related quality of life (HRQL) in chronic hepatitis $C$ virus infection. Digestive diseases and sciences 2007; 52(10):2531-2539.

13. Kandeel, A., Genedy, M., El-Refai, S., Funk, A. L., Fontanet, A., \& Talaat, M. The prevalence of hepatitis C virus infection in Egypt 2015: implications for future policy on prevention and treatment. Liver International 2017; 37(1), 4553.

14. Kroenke, K., Spitzer, R. L., \& Williams, J. B. The Patient Health Questionnaire-2: validity of a two-item depression screener. Medical care 2003; 1284-1292.

15. Leroy V, Angus P, Bronowicki JP, et al. Daclatasvir, sofosbuvir, and ribavirin for hepatitis $C$ virus genotype 3 and advanced liver disease: A randomized phase III study (ALLY3+). Hepatology. 2016; 63:1430-1441.

16. Manos MM, Ho CK, Murphy RC, Shvachko VA. Physical, social, and psychological consequences of treatment for hepatitis C: a community-based evaluation of patient-reported outcomes. Patient 2013; 6(1):23-34.

17. Maor Y, Malnick SD, Melzer E, Leshno M. Treatment of chronic hepatitis $\mathrm{C}$ in the aged-does it impact life expectancy? A decision analysis. PLoS One 2016; 11(7):e0157832.

18. Ministry of Health and Population [Egypt], El-Zanaty and Associates [Egypt], and ICF International. Egypt Health Issues Survey 2015. Ministry of Health and Population and ICF International, Cairo. https://dhspr ogram .com/pubs/pdf/FR313 /FR31 pdf (2015). Accessed 15 Jan 2018.

19. Nappi, A., Perrella, A., Bellopede, P., Lanza, A., Izzi, A., Spatarella, M., \& Sbreglia, C. Safety of new DAAs for chronic HCV infection in a real life experience: role of a surveillance network based on clinician and hospital pharmacist. Infectious Agents and Cancer 2017; 12(1), 12.

20. Omran D, Alboraie M, Zayed RA, Wifi MN, Naguib M, Eltabbakh $M$, Abdellah $M$, Sherief AF, Maklad $S$, Eldemellawy HH, Saad OK, Khamiss DM and El Kassas M. Towards hepatitis C virus elimination: Egyptian experience, achievements and limitations. World J Gastroenterol 2018; 24(38): 4330-4340

21. Pariente, A., Arpurt, J. P., Rémy, A. J., Rosa-Hézode, I., Causse, X., Heluwaert, F., \& Salloum, H. Effects of age on treatment of chronic hepatitis $\mathrm{C}$ with direct acting antivirals. Annals of hepatology 2019; 18(1), 193-202.

22. Pugh, R., Murray-Lyon, I. M., Dawson, J. L., Pietroni, M. C., \& Williams, R. Transection of the oesophagus for bleeding oesophageal varices. British journal of surgery 1973; 60(8), 646-649.

23. Ruane $\mathbf{P J}$, Ain D, Stryker $\mathbf{R}$ et al. Sofosbuvir plus ribavirin for the treatment of chronic genotype 4 hepatitis $C$ virus infection in patients of Egyptian ancestry. J Hepatol 2015; 62(5):1040-1046.

24. Ruane, P. J., Ain, D., Stryker, R., Meshrekey, R., Soliman, M., Wolfe, P. R., \& Massetto, B. Sofosbuvir plus ribavirin for the treatment of chronic genotype 4 hepatitis $C$ virus infection in patients of Egyptian ancestry. Journal of hepatology 2015; 62(5): 1040-1046.

25. Sandmann, L., Schulte, B., Manns, M. P., \& Maasoumy, B. Treatment of chronic hepatitis C: efficacy, side effects and complications. Visceral medicine 2019; 35(3), 161-170.

26. Scheel, T. K., \& Rice, C. M. Understanding the hepatitis C virus life cycle paves the way for highly effective therapies. Nature medicine 2013, 19(7), 837-849.

27. Sherigar JM, Gayam V, Khan A, Mukhtar O, Arefiev Y, Khalid M, Siddiqui I, Rangaraju AM, Budhathoki N, Mansour M, Guss D. Clinical efficacy and tolerability of direct-acting antivirals in elderly patients with chronic hepatitis C. European Journal of Gastroenterology \&
Hepatology. 2017; 29(7):767

28. Smith DB, Bukh J, Kuiken C, Muerhoff AS, Rice CM, Stapleton JT, Simmonds P. Expanded classification of hepatitis $C$ virus into 7 genotypes and 67 subtypes: updated criteria and genotype assignment web resource. Hepatology 2014; 59:318-327.

29. Supreme Council and NCCVH. If online write link and when accessed according to the method of citations you follow, 2016.

30. Vermehren, J., Peiffer, K. H., Welsch, C., Grammatikos, G., Welker, M. W., Weiler, N., \& Sarrazin, C. The efficacy and safety of direct acting antiviral treatment and clinical significance of drug-drug interactions in elderly patients with chronic hepatitis $C$ virus infection. Alimentary pharmacology \& therapeutics 2016; 44(8), 856-865.

31. World Health Organization. Proposed working definition of an old person in Africa. http://www.who.int/healt hinfo /surve y/agein gdefn old/en/. Accessed 11 Jan 2018.

32. Younossi ZM, Stepanova M, Afdhal N, Kowdley KV, Zeuzem S, Henry L, Hunt SL, Marcellin P. Improvement of health-related quality of life and work productivity in chronic hepatitis $C$ patients with early and advanced fibrosis treated with ledipasvir and sofosbuvir. J Hepatol. 2015; 63(2):337-45.

33. Younossi ZM, Stepanova M, Henry L, Gane E, Jacobson IM, Lawitz E, Nelson D, Nader F, Hunt S. Minimal impact of sofosbuvir and ribavirin on health related quality of life in Chronic Hepatitis C (CH-C) J Hepatol. 2014;60(4):741-7. 